\title{
Prevalence of and risk factors for asthma in off-reserve Aboriginal children and adults in Canada
}

\author{
Hsiu-Ju Chang MSc${ }^{1}$, Jeremy Beach MD², Ambikaipakan Senthilselvan PhD ${ }^{1}$
}

\author{
H-J Chang, J Beach, A Senthilselvan. Prevalence of and risk factors \\ for asthma in off-reserve Aboriginal children and adults in Canada \\ Can Respir J 2012;19(6):e68-e74.
}

Only a few studies have investigated asthma morbidity in Canadian Aboriginal children. In the present study, data from the 2006 Aboriginal Peoples Survey were used to determine the prevalence and risk factors for asthma in Canadian Aboriginal children six to 14 years of age and adults 15 to 64 years of age living off reserve. The prevalence of asthma was $14.3 \%$ in children and $14.0 \%$ in adults. Children and adults with Inuit ancestry had a significantly lower prevalence of asthma than those with North American Indian and Métis ancestries. Factors significantly associated with ever asthma in children included male sex, allergy, low birth weight, obesity, poor dwelling conditions and urban residence. In adults, factors associated with ever asthma varied among Aboriginal groups; however, age group, sex and urban residence were associated with ever asthma in all four Aboriginal groups. The prevalence of asthma was lower in Aboriginal children and higher in Aboriginal adults compared with that reported for the Canadian population. Variation in the prevalence of and risk factors for asthma among Aboriginal ancestry groups may be related to genetic and environmental factors that require further investigation.

Key Words: Aboriginal; Adults; Asthma; Children; Prevalence; Risk factors
A sthma was a rare condition among the Aboriginal population during the middle part of the 20 th century. In a retrospective review of admissions from 1946 to 1963 at one Edmonton (Alberta) hospital, only three cases of asthma were identified in the Aboriginal population (1). However, more recent studies conducted in Saskatchewan $(2,3)$ reported increases in asthma prevalence and hospitalization rates in preschool children and older adults among Aboriginal populations. Registered Indian and other Saskatchewan children $\leq 4$ years of age had similar asthma hospitalization rates in the early 1970s; however, this pattern changed in the late 1980s, with registered Indian children having asthma hospitalization rates three times greater than rates observed in other children (2). In another study from Saskatchewan (3), children zero to four years of age and adults 35 to 64 years of age in the registered Indian population had a greater asthma prevalence than persons in other urban or rural populations during the study period (1991 to 1998) (3). However, a study from Alberta (4) showed that emergency and office visits for asthma and chronic obstructive pulmonary disease were greater among Aboriginal populations than non-Aboriginal populations in all age groups in 1996/1997. In an analysis of the data from the National Longitudinal Survey of Children and Youth conducted in the Yukon, Nunavut and Northwest Territories (5), the prevalence of asthma was lower in Aboriginal children than in non-Aboriginal children, whereas the prevalence of current wheeze was greater in Aboriginal children. In a re-analysis of the 1987 Survey of American Indians and Alaska Native children one to 17 years of age (6), the prevalence of asthma was $7.06 \%$, which was slightly lower than that reported for the United States population. However, the same group of researchers conducted a retrospective analysis of Washington state hospitalization data for 1987 through 1996 and reported that hospitalization rates for

\section{La prévalence et les facteurs de risque d'asthme chez les enfants et les adultes autochtones du Canada}

Seules quelques études ont porté sur la morbidité de l'asthme chez les enfants autochtones du Canada. Dans la présente étude, les données de l'Enquête sur les enfants autochtones de 2006 ont permis de déterminer la prévalence et les facteurs de risque d'asthme chez les enfants autochtones canadiens de six à 14 ans et chez les adultes de 16 à 64 ans qui vivent hors réserve. La prévalence d'asthme s'élevait à 14,3 \% chez les enfants et à 14,0 \% chez les adultes. Les enfants et les adultes d'ascendance inuite présentaient une prévalence considérablement plus faible que ceux d'ascendance indienne d'Amérique ou métisse. Les facteurs associés de manière significative à l'asthme à un moment ou à un autre chez les enfants incluaient le sexe masculin, les allergies, le petit poids de naissance, l'obésité, les mauvaises conditions de logement et un milieu de vie urbain. Chez les adultes, ces facteurs variaient selon les groupes autochtones, mais le groupe d'âge, le sexe et un milieu de vie urbain s'associaient à l'asthme à un moment ou à un autre dans les quatre groupes autochtones. La prévalence d'asthme était plus faible chez les enfants autochtones et plus élevée chez les adultes autochtones que celle déclarée dans la population canadienne. La variation de prévalence et de facteurs de risque d'asthme chez les groupes d'ascendance autochtone pourrait être liée à des facteurs génétiques et environnementaux qui doivent faire l'objet de recherches plus approfondies.

asthma and bronchiolitis among American Indian and Alaska Native children $>1$ year of age were two to three times greater than that observed for all other children combined (7). In a recent study involving Alaska Native children six to 13 years of age using the International Study of Asthma and Allergy in Children (ISAAC) protocol, the prevalence of asthma was lower among children from rural areas than in those from urban areas (8). In a study of Inuit school children in Northern Quebec, 6.0\% of the children had parental report of wheezing in the previous 12 months and 5.3\% had evidence of atopy (9). In an analysis of the 2001 Aboriginal Peoples Survey (APS), the prevalence of asthma was $11.6 \%$ among Aboriginal adolescents and adults, and $12.1 \%$ among Aboriginal children (10).

In summary, to date, there is conflicting information about the risk of asthma among Aboriginal groups in Canada, but some suggestion that this particular group may be at increased risk. We used the data from the 2006 APS in our study to determine the prevalence of and risk factors for asthma in Canadian Aboriginal children six to 14 years of age, and adults 15 to 64 years of age living off reserve.

\section{METHODS}

Data from the 2006 APS, conducted from October 2006 to March 2007 by Statistics Canada, were used in the present study. The objective of the 2006 APS was to understand the social and economic conditions of Aboriginal peoples in Canada. Aboriginal people living in Indian settlements or on reserves were excluded from the survey (11). Aboriginal people were defined as persons with North American Indian (NAI), Métis and Inuit ancestries or identities, and those who were registered Indians or band members. The 2006 census long form contained screening questions on ethnic or cultural origins, selfidentification of Aboriginal, membership of an Indian Band/First

${ }^{1}$ School of Public Health; ${ }^{2}$ Division of Preventive Medicine, Department of Medicine, University of Alberta, Edmonton, Alberta

Correspondence: Dr Ambikaipakan Senthilselvan, School of Public Health, 3-349 Edmonton Clinic Health Academy, 11405-87 Avenue,

Edmonton, Alberta T6G 1C9. Telephone 780-492-6505, fax 780-492-0364, e-mail sentil@ualberta.ca 
Nations and Treaty Indian or registered Indian status. Persons with a positive response to any one of these questions were considered as the target population for the 2006 APS. A multistage, stratified random sampling design was used in the 2006 APS to select the participants. To reduce the survey burden for the respondents, persons who were part of the National Longitudinal Survey of Children and Youth and other postcensal surveys were removed from the initial sample chosen for APS 2006. This resulted in a sample of 61,041 persons for the 2006 APS. After excluding nonrespondents and those who reported not belonging to the Aboriginal population later in the 2006 APS, the final sample size for the 2006 APS was 48,921, yielding a response rate of $80.1 \%$. Each person was assigned a survey design weight provided by Statistics Canada that was based on adjustment for nonresponse and overlap with other surveys (11). The survey design weights were considered in the statistical analysis to obtain valid estimates for the population parameters.

Independent questionnaires for children and youth (six to 14 years of age) and adults ( $\geq 15$ years of age) were administered in the 2006 APS. The questionnaires covered a broad range of questions about demographic, social and economic background of Aboriginal people living off reserve. Parents or guardians completed the Child and Youth questionnaire for children six to 14 years of age. With consent from parents, children 12 to 14 years of age were allowed to answer some of the questions. Parental consent was also obtained for adolescents 15 to 17 years of age. Participants $\geq 15$ years of age completed their own questionnaire. Paper questionnaires were used for data collection. The questionnaires were initially prepared in English and French and were translated into 20 Aboriginal languages to facilitate communication. Personal interviews were conducted in the Inuit region, Labrador and in the Northwest Territories (except Yellowknife), while telephone interviews were implemented in the rest of Canada. The confidential 2006 APS database was accessed at the Research Data Centre, University of Alberta (Edmonton, Alberta) after receiving approval from Statistics Canada.

'Ever asthma' in children was determined by the response to the question "Does he/she have asthma that has been diagnosed by a doctor, nurse or health professional?" in the Children and Youth questionnaire. The response to the question "Have you been told by a doctor, nurse or other health professional that you have asthma?" in the Adult Core questionnaire was used to determine 'ever asthma' in adolescents and adults. 'Current asthma' in children was determined by the response to the question "Have you had an attack of asthma in the past 12 months?" in the Children and Youth questionnaire. Because there were no questions regarding recent asthma attacks or symptoms in the Adult Core questionnaire, current asthma was not determined in the adults. Age of asthma onset was determined by the response to the question "At what age were you first told that you have asthma?" in the Adult Core questionnaire. Based on the response to this question, adults were categorized into three mutually exclusive groups: subjects with no report of asthma; subjects with asthma onset at 14 years of age or earlier; and subjects with asthma onset at 15 years of age or later.

Several demographic, early childhood, health-related, household and socioeconomic factors were considered in the study: demographic factors (urban/nonurban residence, Aboriginal ancestries, sex, age and region of residence); early childhood factors (low birth weight, ever breastfed and day care attendance); health-related factors (allergy, psychological difficulties, standard weight, smoking habit, difficulties with accessing health care, general health status and ever consultation with a health care worker in the past 12 months); household factors (dwelling condition, number of siblings and number of individuals in the household); and socioeconomic factors (low income, parental education level, education level, labour activity in the past week and rented/owned house).

\section{Statistical analysis}

Survey design weights were included in the estimations of prevalence of ever and current asthma, and relative frequencies of factors were obtained using rounded denominators and numerators. Multiple logistic regression with survey design weights was used to estimate ORs of possible risk factors for current and ever asthma. Variances were estimated using 1000 bootstrap weights that were provided by Statistics Canada. In addition, variances were multiplied by a factor of 16 to allow for the complex sampling design, which was achieved by including a Fay adjustment factor of 0.75 in the SVSET command in STATA (Stata Corporation, USA).

The purposeful selection method was adopted in model building procedures. Factors with $\mathrm{P}<0.20$ in the univariate logistic regression models were initially considered in the multiple logistic regression models, and only the clinically important, statistically significant $(\mathrm{P}<0.05)$ and borderline significant factors were retained in the final multiple logisitic regression model. SVY commands in STATA version 10.0 were used to conduct all statistical analyses in the present study.

\section{RESULTS}

Children (six to 14 years of age)

As shown in Table 1, characteristics of children from the NAI, Métis and multiple ancestry groups were similar, whereas several characteristics of Inuit children were different from the other groups. The majority of Inuit children $(81.7 \%)$ resided in nonurban areas of the northern territories (56.4\%) and Quebec (21.5\%). They were more obese $(24.7 \%)$, less prone to allergies $(9.5 \%)$, more often residing in dwellings needing major repairs (26.8\%), living with more siblings $(75.4 \%)$ and more often reporting poor general health (24.5\%). In addition, parental education levels were lower for Inuit children compared with children from other Aboriginal groups.

The prevalence of current and ever asthma among all Aboriginal children combined was $5.7 \%$ and $14.3 \%$, respectively. Among those with ever asthma, $18.1 \%$ experienced asthma-related activity limitation and $65.2 \%$ had been taking asthma medication on a regular basis. As shown in Table 2, the prevalence of ever asthma was similar in younger and older children, and was greater in boys than in girls. The prevalence of ever asthma was significantly lower in Inuit children (5.2\%) compared with children in the other three ancestry groups (NAI 14.2\%; Métis 15.1\%; multiple ancestry 15.6\%).

Because Inuit children live mainly in the northern territories, this region had the lowest prevalence of ever asthma among the six regions of Canada. Children with low birth weight and allergies had a significantly greater prevalence of ever asthma than those without the conditions. Children from families with lower income had a significantly higher prevalence of asthma than those from families with higher income. Not surprisingly, health consultation or hospitalization in the previous 12 months and poor general health, which are indicators of asthma morbidity, were significantly associated with increased asthma prevalence. These variables were not considered to be potential risk factors in the multiple logistic regression analysis.

Results from the multiple logistic regression analysis are shown in Table 2. Inuit children were less likely to have ever asthma (OR 0.61) compared with NAI children after controlling for other factors. Residing in nonurban areas was protective of ever asthma in children. Children with low birth weight were more likely to have ever asthma (OR 1.44) compared with the children with normal birth weight. Children who were overweight or obese were significantly more likely to report ever asthma than children of normal weight. The presence of allergies was significantly associated with ever asthma, with an OR of 5.99 (95\% CI 5.26 to 6.84) for the association in the multiple logistic regression. Children living in dwellings needing major repairs were more likely to have ever asthma (OR 1.27) compared with those living in dwellings needing no repairs. There were borderline significant associations between day care attendance, psychological or nervous difficulties, and economic family income and ever asthma.

Interaction effects of ancestry with allergies and sex were statistically significant in the multiple logistic regression model of ever asthma. Among boys with allergy, the prevalence of ever asthma was higher in Inuit and Métis children than in NAI children, whereas 
TABLE 1

Distribution of personal characteristic, demographic and household factors according to Aboriginal groups in children

\begin{tabular}{|c|c|c|c|c|}
\hline \multirow[b]{2}{*}{ Factor } & \multicolumn{4}{|c|}{ Aboriginal group, $\%$} \\
\hline & NAI & Métis & Inuit & Multiple \\
\hline \multicolumn{5}{|l|}{ Age, years } \\
\hline $6-9$ & 59.1 & 58.1 & 54.8 & 57.7 \\
\hline $10-14$ & 40.9 & 41.9 & 45.3 & 42.3 \\
\hline Female sex & 47.8 & 50.1 & 45.8 & 49.0 \\
\hline \multicolumn{5}{|l|}{ Residence } \\
\hline Urban & 75.9 & 69.0 & 18.3 & 70.6 \\
\hline Nonurban & 24.0 & 31.0 & 81.7 & 29.4 \\
\hline \multicolumn{5}{|l|}{ Region of residence (Canada) } \\
\hline Atlantic & 8.0 & 5.4 & 8.9 & 4.1 \\
\hline Quebec & 13.7 & 4.7 & 21.5 & 15.0 \\
\hline Ontario & 31.2 & 19.3 & 6.1 & 20.6 \\
\hline Prairies & 28.0 & 53.0 & 4.8 & 44.5 \\
\hline British Columbia & 16.4 & 16.6 & 2.4 & 13.5 \\
\hline Territories & 2.6 & 0.9 & 56.4 & 2.2 \\
\hline Low birth weight $(<2500 g)$ & 6.4 & 5.8 & 5.6 & 5.9 \\
\hline Ever breastfed & 69.0 & 70.3 & 61.8 & 71.4 \\
\hline \multicolumn{5}{|l|}{ Body mass index } \\
\hline Normal or underweight & 59.5 & 59.6 & 49.5 & 61.7 \\
\hline Overweight & 22.9 & 24.4 & 25.6 & 21.5 \\
\hline Obese & 17.5 & 16.0 & 24.7 & 16.8 \\
\hline Allergies & 19.3 & 18.2 & 9.5 & 20.7 \\
\hline $\begin{array}{l}\text { Psychological/nervous } \\
\text { difficulties }\end{array}$ & 4.5 & 2.7 & 1.3 & 4.3 \\
\hline \multicolumn{5}{|l|}{ Dwelling condition } \\
\hline No need of repair & 47.3 & 48.8 & 38.9 & 45.0 \\
\hline In need of minor repairs & 37.0 & 37.2 & 34.2 & 40.1 \\
\hline In need of major repairs & 15.7 & 14.1 & 26.8 & 14.9 \\
\hline \multicolumn{5}{|l|}{ Number of siblings } \\
\hline$\leq 1$ & 40.7 & 48.4 & 24.6 & 42.7 \\
\hline$\geq 2$ & 59.3 & 51.6 & 75.4 & 57.3 \\
\hline Day care attendance & 59.9 & 64.1 & 57.1 & 64.3 \\
\hline \multicolumn{5}{|l|}{ Family income/year, \$ } \\
\hline$>30,000$ & 73.5 & 80.5 & 81.8 & 76.9 \\
\hline$\leq 30,000$ & 26.5 & 19.5 & 18.2 & 23.1 \\
\hline Health consult in past 12 months & 73.0 & 69.4 & 68.3 & 74.0 \\
\hline Hospitalization in past 12 months & 2.8 & 2.0 & 5.0 & 3.6 \\
\hline \multicolumn{5}{|l|}{ General health status } \\
\hline Excellent or very good & 83.5 & 84.7 & 75.5 & 83.8 \\
\hline Good, fair or poor & 16.5 & 15.3 & 24.5 & 16.2 \\
\hline
\end{tabular}

NAI North American Indian

among girls with allergy, the prevalence of ever asthma was the lowest in Inuit children. Among both boys and girls without allergy, the prevalence of ever asthma was lower in Inuit children compared with NAI and Métis children.

Factors associated with current asthma were also investigated using logistic regression analysis (data not shown). The OR of current asthma for Inuit children compared with NAI children was significant only in the univariate analysis. Sex, residing in a nonurban area, low birth weight, obesity, allergies, psychological or nervous difficulties, and dwelling needing major repairs were significantly associated with current asthma in the multiple logistic regression analysis.
TABLE 2

Prevalence and ORs from the univariate and multivariate logistic regression for ever asthma by potential risk factors in Aboriginal children

\begin{tabular}{|c|c|c|c|}
\hline \multirow[b]{2}{*}{ Factors } & \multirow{2}{*}{$\begin{array}{c}\text { Prevalence, } \\
\% \\
\end{array}$} & \multicolumn{2}{|c|}{ OR (95\% Cl) } \\
\hline & & Univariate & Multivariate \\
\hline \multicolumn{4}{|l|}{ Age, years } \\
\hline $6-9$ & 14.5 & 1.00 & \\
\hline $10-14$ & 14.1 & $0.97(0.87-1.01)$ & \\
\hline \multicolumn{4}{|l|}{ Sex } \\
\hline Female & 11.4 & 1.00 & 1.00 \\
\hline Male & 17.1 & $1.61(1.43-1.80)^{\ddagger}$ & $1.52(1.33-1.74)^{\ddagger}$ \\
\hline \multicolumn{4}{|l|}{ Aboriginal ancestry } \\
\hline North American Indian & 14.2 & 1.00 & 1.00 \\
\hline Métis & 15.1 & $1.07(0.94-1.22)$ & $1.13(0.97-1.32)$ \\
\hline Inuit & 5.8 & $0.37(0.28-0.50)^{\ddagger}$ & $0.61(0.43-0.87)^{\dagger}$ \\
\hline Multiple ancestries & 15.6 & $1.11(0.96-1.29)$ & $1.07(0.91-1.26)$ \\
\hline \multicolumn{4}{|l|}{ Residence } \\
\hline Urban & 15.4 & 1.00 & 1.00 \\
\hline Nonurban & 11.7 & $0.73(0.65-0.82)^{\ddagger}$ & $0.82^{\dagger}(0.72-0.94)$ \\
\hline \multicolumn{4}{|c|}{ Region of residence (Canada) } \\
\hline Prairies & 14.7 & 1.00 & NA \\
\hline Atlantic & 16.2 & $1.12(0.93-1.35)$ & \\
\hline Quebec & 16.2 & $1.12(0.95-1.34)$ & \\
\hline Ontario & 14.6 & $1.00(0.85-1.17)$ & \\
\hline British Columbia & 13.2 & $0.89(0.75-1.05)$ & \\
\hline Territories & 5.9 & $0.36(0.28-0.48)^{\ddagger}$ & \\
\hline \multicolumn{4}{|l|}{ Low birth weight (<2500 g) } \\
\hline No & 14.0 & 1.00 & 1.00 \\
\hline Yes & 19.1 & $1.45(1.20-1.77)^{\ddagger}$ & $1.44(1.15-1.80)^{\dagger}$ \\
\hline \multicolumn{4}{|l|}{ Ever breastfed } \\
\hline No & 14.7 & 1.00 & \\
\hline Yes & 14.3 & $0.97(0.86-1.10)$ & \\
\hline \multicolumn{4}{|l|}{ Daycare attendance } \\
\hline No & 13.6 & 1.00 & 1.00 \\
\hline Yes & 14.9 & $1.12(0.99-1.26)^{\S}$ & $1.13(0.99-1.29)^{\S}$ \\
\hline \multicolumn{4}{|l|}{ Body mass index } \\
\hline Normal/underweight & 13.7 & 1.00 & 1.00 \\
\hline Overweight & 15.4 & $1.15(1.00-1.32)^{\S}$ & $1.17(1.00-1.38)^{\star}$ \\
\hline Obese & 15.6 & $1.17(1.00-1.37)^{\S}$ & $1.24(1.05-1.48)^{*}$ \\
\hline \multicolumn{4}{|l|}{ Allergies } \\
\hline No & 8.9 & 1.00 & 1.00 \\
\hline Yes & 37.2 & $6.06(5.35-6.85)^{\ddagger}$ & $5.99(5.26-6.84)^{\ddagger}$ \\
\hline \multicolumn{4}{|c|}{ Psychological/nervous difficulties } \\
\hline No & 14.0 & 1.00 & 1.00 \\
\hline Yes & 22.1 & $1.74(1.39-2.19)^{\ddagger}$ & $1.27(0.97-1.66)^{\S}$ \\
\hline \multicolumn{4}{|l|}{ Dwelling condition } \\
\hline No need of repairs & 13.7 & 1.00 & 1.00 \\
\hline In need of minor repairs & 14.5 & $1.07(0.95-1.21)$ & $1.08(0.93-1.24)$ \\
\hline In need of major repairs & 15.8 & $1.18(1.01-1.39)^{\dagger}$ & $1.27(1.06-1.54)^{*}$ \\
\hline \multicolumn{4}{|l|}{ Number of siblings } \\
\hline$\leq 1$ & 14.9 & 1.00 & \\
\hline$\geq 2$ & 13.9 & $0.93(0.83-1.04)$ & \\
\hline \multicolumn{4}{|l|}{ Family income/year, \$ } \\
\hline$>30,000$ & 13.7 & 1.00 & 1.00 \\
\hline$\leq 30,000$ & 16.3 & $1.23(1.08-1.41)^{\dagger}$ & $1.16(0.99-1.35)^{\S}$ \\
\hline Health consultation in pas & st 12 months & & \\
\hline No & 8.9 & 1.00 & NA \\
\hline Yes & 16.5 & $2.03(1.74-2.38)^{\ddagger}$ & \\
\hline Hospitalization in past 12 & months & & \\
\hline No & 14.1 & 1.00 & NA \\
\hline Yes & 22.6 & $1.78(1.35-2.34)^{\ddagger}$ & \\
\hline General health status & & & \\
\hline Excellent or very good & 11.6 & 1.00 & NA \\
\hline Good, fair or poor & 27.8 & $2.92(2.59-3.30)^{\ddagger}$ & \\
\hline
\end{tabular}

${ }^{*} P<0.05 ;{ }^{\dagger} P<0.01 ;{ }^{\ddagger} P<0.001 ;{ }^{\S} P<0.10$. NA Not considered for multiple logistic regression 
Adults ( $\geq 15$ years of age)

The distribution of characteristics in the four Aboriginal adult groups was similar to those similar to those in the Aboriginal child groups (Table 3). Smoking was more prevalent in Inuit adults $(67.9 \%)$ than in the other three groups: NAI (42.1\%), Métis (37.9\%) and multiple ancestries (39.0\%). Home owenership was less common among Inuit adults compared with the other three groups. The proportion of persons with some postsecondary education was lower in Inuit adults compared with other Aboriginal groups.

Among adults, the prevalence of ever asthma was significantly lower in the older age group, higher in females and lower in Inuit adults (Table 4). Residing in nonurban areas and living in homes with five or more persons were protective of ever asthma in adults. The prevalence of asthma was greater among those who reported being obese, living in own home, having lower family income and facing difficulties in accessing health care. Similar to the analysis performed for children, an initial multivariate analysis was conducted with all of the Aboriginal ancestry groups combined. However, the effect of several factors on ever asthma varied among the four ancestry groups, resulting in significant interactions. To simplify the interpretation from the multivariate analysis, a stratified analysis according to ancestry group was conducted, with results shown in Table 5. Living in nonurban areas was a significant protective factor for ever asthma in all four ancestry groups. Male sex was protective for ever asthma in all of the ancestry adult groups except Inuit adults. Being obese and difficulty in accessing health care were risk factors for asthma among NAIs, Métis and multiple ancestry groups. Education above high school and higher family income were protective for ever asthma.

Factors associated with early and late-onset asthma were examined by conducting independent analysis among Aboriginal adults who reported a diagnosis of asthma before or after 15 years of age, respectively (data not shown). Being obese was a risk factor for early onset asthma and higher family income was protective for late-onset asthma

\section{DISCUSSION}

In our study, the prevalence of ever asthma was found to be $14.3 \%$ in Aboriginal children six to 14 years years of age, which is slightly lower than the prevalence of asthma reported in the general Canadian population (12). In the National Longitudinal Survey of Children and Youth conducted in 2000/2001, the prevalence of ever asthma in Canadian children was $15.7 \%$ and $17.6 \%$ in the age groups of six to nine years, and 10 to 11 years of age, respectively (12). In a study conducted in the northern territories of Canada (5), asthma prevalence was also found to be lower in Aboriginal children zero to 11 years of age compared with non-Aboriginal children. Although the prevalence of asthma in Aboriginal children was lower than that in nonAboriginal children, the prevalence appears to have increased over time in Aboriginal children six to 14 years of age. The prevalence of ever asthma was $12.1 \%$ in the 2001 APS compared with $14.3 \%$ observed in our study using the 2006 APS, corresponding to a $2.2 \%$ increase over the five-year period (10). In our study, $65.2 \%$ of children with ever asthma reported regularly taking asthma medications, indicating that compliance with taking medications was quite high among Aboriginal children. In addition, the prevalence of taking asthma medication among all Aboriginal children was 9.3\% (65.2\% of ever asthma prevalence, $14.3 \%$ ), which was $3.6 \%$ higher than the current asthma prevalence $(5.7 \%)$, raising the possibility that asthma may be sufficiently well controlled among some Aboriginal children who do not consider themselves to have current asthma.

In contrast to the results observed for children, Aboriginal adults 15 to 64 years of age had a higher prevalence of asthma (14.0\%) than that reported in the Canadian population $\geq 12$ years of age (13). Similar to the results observed in Aboriginal children, asthma prevalence in Aboriginal adults increased from $11.6 \%$ in the 2001 APS to $14.0 \%$ in the present study using the 2006 APS (7). An increase of asthma-related emergency room and physician office visits was
TABLE 3

Distribution of personal characteristic, demographic and household factors according to Aboriginal group in adults

\begin{tabular}{|c|c|c|c|c|}
\hline \multirow[b]{2}{*}{ Factors } & \multicolumn{4}{|c|}{ Aboriginal group, $\%$} \\
\hline & NAI & Métis & Inuit & Multiple \\
\hline \multicolumn{5}{|l|}{ Residence } \\
\hline Urban & 76.6 & 71.2 & 23.0 & 73.5 \\
\hline Nonurban & 23.4 & 28.8 & 77.0 & 26.5 \\
\hline \multicolumn{5}{|l|}{ Sex } \\
\hline Female & 55.6 & 56.0 & 50.1 & 51.8 \\
\hline \multicolumn{5}{|l|}{ Age, years } \\
\hline $15-34$ & 45.2 & 48.7 & 56.2 & 40.7 \\
\hline $35-64$ & 54.8 & 51.3 & 43.8 & 59.3 \\
\hline \multicolumn{5}{|c|}{ Region of residence (Canada) } \\
\hline Atlantic & 8.8 & 5.9 & 15.1 & 5.8 \\
\hline Quebec & 19.5 & 6.2 & 19.5 & 19.7 \\
\hline Ontario & 31.9 & 22.6 & 6.5 & 22.8 \\
\hline Prairies & 22.0 & 48.7 & 4.8 & 37.2 \\
\hline British Columbia & 15.4 & 15.6 & 2.7 & 12.8 \\
\hline Territories & 2.4 & 0.9 & 51.4 & 1.6 \\
\hline \multicolumn{5}{|l|}{ Labour activity in past week } \\
\hline Yes & 63.3 & 68.5 & 53.0 & 66.3 \\
\hline \multicolumn{5}{|l|}{ Body mass index } \\
\hline Normal or underweight & 42.9 & 44.9 & 43.7 & 40.0 \\
\hline Overweight & 33.9 & 32.0 & 33.9 & 34.8 \\
\hline Obese & 23.2 & 23.0 & 22.4 & 25.2 \\
\hline \multicolumn{5}{|l|}{ Type of smoker } \\
\hline Nonsmoker & 33.6 & 38.9 & 17.8 & 34.9 \\
\hline Ever smoker & 24.2 & 23.3 & 14.3 & 26.1 \\
\hline Current smoker & 42.1 & 37.8 & 67.9 & 39.0 \\
\hline \multicolumn{5}{|l|}{ Dwelling condition } \\
\hline No need of repair & 50.7 & 53.2 & 43.0 & 51.3 \\
\hline In need of minor repair & 35.2 & 35.2 & 31.3 & 35.2 \\
\hline In need of major repair & 14.2 & 11.6 & 25.7 & 13.5 \\
\hline \multicolumn{5}{|l|}{ Rented/owned house } \\
\hline Own & 57.9 & 67.9 & 37.5 & 64.4 \\
\hline Rent & 42.1 & 32.1 & 62.5 & 35.6 \\
\hline \multicolumn{5}{|l|}{ Persons in the household, $\mathrm{n}$} \\
\hline$\leq 4$ & 83.0 & 81.8 & 54.4 & 83.4 \\
\hline$\geq 5$ & 17.0 & 18.2 & 45.6 & 16.6 \\
\hline \multicolumn{5}{|l|}{ Education level } \\
\hline$\leq$ High school & 43.7 & 45.6 & 60.6 & 38.9 \\
\hline Some postsecondary & 56.3 & 54.4 & 39.4 & 61.1 \\
\hline \multicolumn{5}{|l|}{ Family income/year, $\$$} \\
\hline$>30,000$ & 71.9 & 78.1 & 77.6 & 75.3 \\
\hline$\leq 30,000$ & 28.1 & 21.9 & 22.4 & 24.7 \\
\hline \multicolumn{5}{|c|}{ Difficulty with access to health care } \\
\hline Yes & 11.5 & 9.1 & 9.1 & 12.5 \\
\hline \multicolumn{5}{|c|}{ Health consultation in past 12 months } \\
\hline Yes & 90.4 & 88.5 & 88.3 & 90.1 \\
\hline \multicolumn{5}{|c|}{ Hospitalization in past 12 months } \\
\hline Yes & 10.2 & 9.7 & 12.1 & 10.7 \\
\hline \multicolumn{5}{|l|}{ General health status } \\
\hline Excellent or very good & 58.7 & 62.0 & 53.6 & 59.8 \\
\hline Good, fair or poor & 41.3 & 38.0 & 46.4 & 40.2 \\
\hline
\end{tabular}

NAI North American Indian

also reported in studies based in Alberta and Saskatchewan $(3,5,6)$, where the Aboriginal population was more likely to be hospitalized and to have emergency room and physician office visits than the nonAboriginal population (6). 


\section{TABLE 4}

Prevalence and OR from the univariate logistic regression for ever asthma according to potential risk factors in Aboriginal adults

\begin{tabular}{|c|c|c|}
\hline Factor & Prevalence, \% & Univariate OR (95\% CI) \\
\hline \multicolumn{3}{|l|}{ Age, years } \\
\hline $15-34$ & 15.5 & 1.00 \\
\hline $35-64$ & 12.6 & $0.79(0.70-0.88)$ \\
\hline \multicolumn{3}{|l|}{ Sex } \\
\hline Female & 16.2 & 1.00 \\
\hline Male & 11.2 & $0.65(0.58-0.73)^{\star \star \star}$ \\
\hline \multicolumn{3}{|l|}{ Aboriginal ancestry } \\
\hline North American Indian & 13.8 & 1.00 \\
\hline Métis & 13.8 & $1.00(0.88-1.14)$ \\
\hline Inuit & 9.7 & $0.67(0.51-0.88)^{\star \star}$ \\
\hline Multiple ancestries & 15.3 & $1.13(0.98-1.30)$ \\
\hline \multicolumn{3}{|l|}{ Residence } \\
\hline Urban & 15.0 & 1.00 \\
\hline Nonurban & 11.2 & $0.71(0.64-0.79)^{\star * *}$ \\
\hline \multicolumn{3}{|c|}{ Region of residence (Canada) } \\
\hline Prairies & 13.1 & 1.00 \\
\hline Atlantic & 13.8 & $1.06(0.91-1.23)$ \\
\hline Quebec & 12.7 & $0.96(0.81-1,14)$ \\
\hline Ontario & 17.7 & $1.43(1.25-1.63)^{\star \star *}$ \\
\hline British Columbia & 12.0 & $0.90(0.77-1.07)$ \\
\hline Territories & 7.1 & $0.50(0.42-0.60)^{\star \star *}$ \\
\hline \multicolumn{3}{|l|}{ Body mass index } \\
\hline Normal/underweight & 13.1 & 1.00 \\
\hline Overweight & 12.2 & $0.93(0.81-1.06)$ \\
\hline Obese & 17.5 & $1.41(1.23-1.62)^{\star \star \star}$ \\
\hline \multicolumn{3}{|l|}{ Dwelling condition } \\
\hline No need of repairs & 13.7 & 1.00 \\
\hline In need of minor repairs & 13.0 & $0.94(0.80-1.12)$ \\
\hline In need of major repairs & 14.7 & $1.09(0.97-1.23)$ \\
\hline \multicolumn{3}{|l|}{ Persons in the household, $\mathrm{n}$} \\
\hline$\leq 4$ & 14.3 & 1.00 \\
\hline$\geq 5$ & 12.6 & $0.86(0.75-0.99)^{*}$ \\
\hline \multicolumn{3}{|l|}{ Type of dwelling } \\
\hline Rented & 12.7 & 1.00 \\
\hline Own & 15.8 & $1.29(1.15-1.44)^{\star \star *}$ \\
\hline \multicolumn{3}{|l|}{ Education level } \\
\hline$\leq$ High school & 14.6 & 1.00 \\
\hline >High school & 13.4 & $0.90(0.81-1.01)$ \\
\hline \multicolumn{3}{|l|}{ Family income/year, \$ } \\
\hline$\leq 30,000$ & 14.4 & 1.00 \\
\hline$>30,000$ & 10.2 & $0.73(0.64-0.81)^{\star \star *}$ \\
\hline \multicolumn{3}{|c|}{ Difficulties in accessing health care } \\
\hline No & 12.9 & 1.00 \\
\hline Yes & 22.5 & $1.96(1.67-2.31)^{\star \star *}$ \\
\hline \multicolumn{3}{|c|}{ Health consultation in past 12 months } \\
\hline No & 10.2 & 1.00 \\
\hline Yes & 14.4 & $1.49(1.20-1.85)^{\star * *}$ \\
\hline \multicolumn{3}{|c|}{ Hospitalization in past 12 months } \\
\hline No & 13.4 & 1.00 \\
\hline Yes & 18.8 & $1.50(1.29-1.74)^{\star \star \star}$ \\
\hline \multicolumn{3}{|l|}{ General health status } \\
\hline Excellent or very good & 10.6 & 1.00 \\
\hline Good, fair or poor & 18.9 & $1.97(1.77-2.20)^{\star * *}$ \\
\hline
\end{tabular}

${ }^{*} P<0.05 ;{ }^{* *} P<0.01 ;{ }^{* *} P<0.001$. NA Not considered for multiple logistic regression
The lower prevalence of asthma in Aboriginal children and higher prevalence in Aboriginal adults compared with those in Canadian children and adults, respectively, raises the possibility that an 'asthma healthy' population of Aboriginal children go on to develop asthma in adulthood, possibly due to environmental factors such as poor housing and indoor air quality, which may affect women more than men. The different pattern seen in the Aboriginal population, when compared with the general Canadian population, may also be influenced by genetics.

In the current study, asthma prevalence varied among Aboriginal groups, with Inuit children and adults having lower asthma prevalence than NAI and Métis ancestry groups. This finding is consistent with the results reported from the analysis of the 2001 APS survey (10). The lower prevalence of asthma in the Inuit population supports the suggestion that genetics play a role in the development of asthma.

In our study, male sex was significantly associated with ever and current asthma in Aboriginal children, although this was reversed in Aboriginal adults, with female sex being significantly associated with ever asthma. Several studies have corroborated these findings in other populations (14). The reasons for this pattern are unknown but hormonal changes at puberty among females may contribute to the increase in genetic susceptibility to the development of asthma (15).

We also found that low birth weight and allergy were risk factors for asthma in Aboriginal children. These findings have also been reported for asthma incidence in non-Aboriginal children in Canada (16). Children with premature birth or low birth weight, and possibly relatively underdeveloped or immature lungs, may have a long-term increased risk of asthma development in later life.

Allergy was a significant risk factor for ever and current asthma among Aboriginal children, with ORs of approximately 6.0 and 7.5, respectively, indicating a large effect of allergy. Previous studies involving non-Aboriginal children have reported that allergy was an important risk factor for the development of asthma $(16,17)$. The data from the 2006 APS did not distinguish between different types of allergies, and the OR reported in the current study indicates the effect of all allergies collectively, including food allergy.

In our study, psychological or nervous difficulties were found to be significantly associated with asthma in Aboriginal children. Over the past two decades, psychological factors have drawn researchers' attention as potential factors associated with asthma. In a study conducted in eight inner-city areas in the United States, asthmatic children four to nine years of age were found to exhibit more behaviour problems (18). An association between asthma and anxiety and depression in adolescents and young adults was reported in a 21-year follow-up birth cohort study in the United States (19). Asthmatic children may perceive themselves with poorer mental health status because of frequent episodes of asthma. The higher anxiety level and negative perception of their health might also induce psychological disorders; however, the temporal sequence could not be determined in the present study and, consequently, it was not possible to identify a possible causative effect. Additionally, one study suggested that the association between psychological difficulties and asthma reflects the effects of common factors associated with both disorders, rather than a direct causal relationship (19).

The current study used Cole's method to define overweight and obesity in children and found a positive association between obesity and asthma (20). Presently, there is no generally accepted method to define overweight and obesity in Canadian Aboriginal children, and Cole's method may have better validity in the Aboriginal population compared with other methods because Cole's method was established from data collected from six different populations. In our study, ORs for ever asthma showed an increasing trend from under or normal weight, overweight, to obesity, although only the association between obesity and ever asthma was statistically significant. Previous studies have reported a positive association between obesity and asthma in non-Aboriginal children (21-23). The association between obesity and asthma may be mediated in two ways. Obese children may have 
TABLE 5

Results from the multiple logistic regression analyses of ever asthma in adults according to Aboriginal group

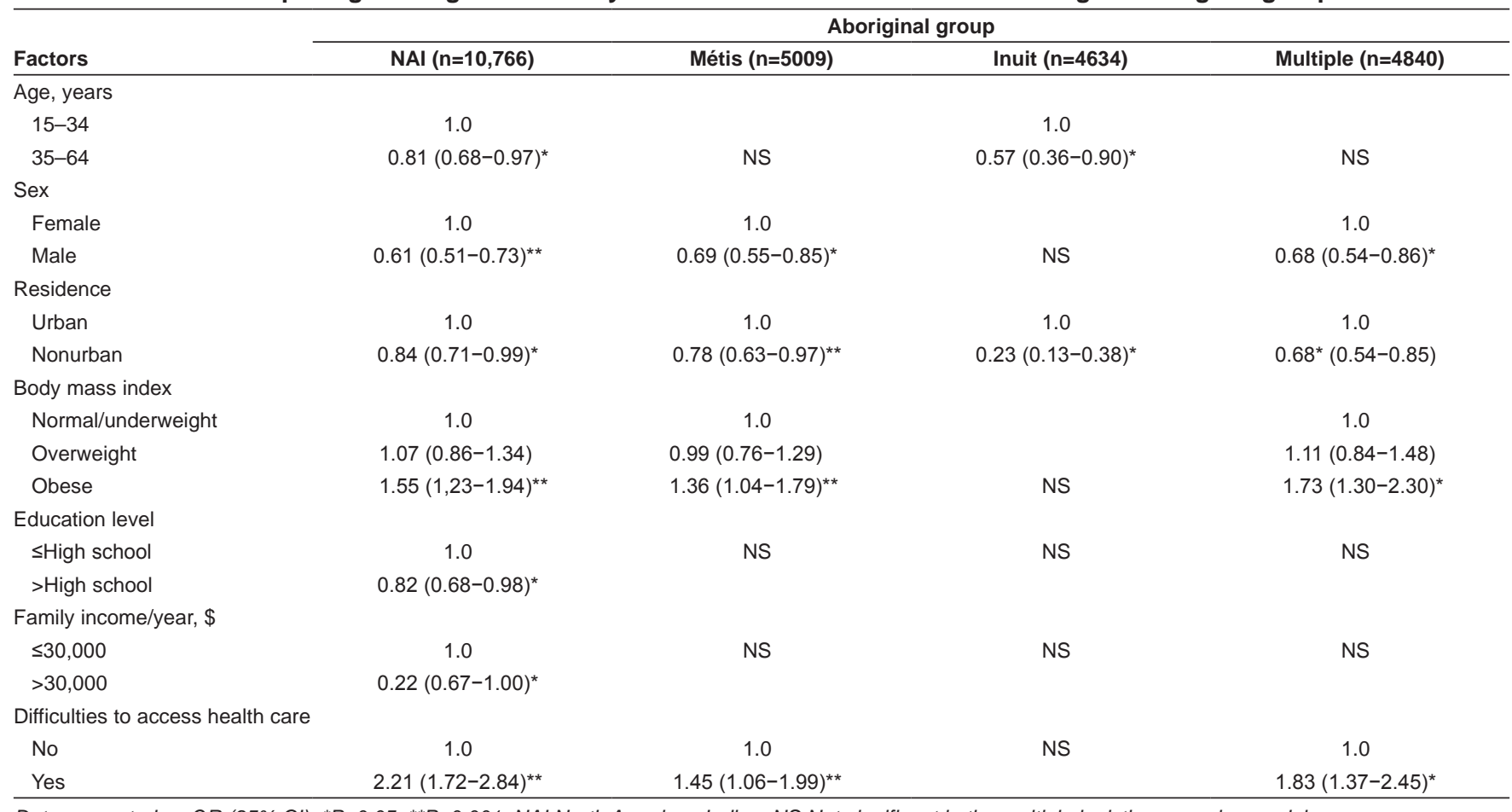

Data presented as OR $(95 \% \mathrm{Cl}) .{ }^{*} P<0.05 ;{ }^{*} P<0.001$. NAI North American Indian; NS Not significant in the multiple logistic regression model

narrower airways and experience more severe inflammatory responses; therefore, the risk of developing asthma may increase. Alternatively, asthmatic children, especially those with more severe asthma, might have difficulties exercising and, therefore, be prone to weight gain. Studies have attempted to clarify the temporal sequence by using a prospective study design, and a higher body mass index was reported as a risk factor for asthma in an Australian birth cohort study following children up to six years of age (24). The relationship between obesity and asthma is complex, and evidence for a causal effect could not be determined in the current study.

Risk factors for asthma in adults varied among Aboriginal ancestry groups in the current study. Female sex was a risk factor for asthma in NAIs, Métis and multiple ancestry groups but not in the Inuit ancestry. Interestingly, rural residence was a protective factor for asthma in all four ancestry groups. In Ontario, subjects living in rural areas had a reduced lifetime risk of physician-diagnosed asthma that was significantly greater compared with those living in urban areas (25).

There were some limitations to the study. The temporal sequence of exposures and outcomes were unclear due to the cross-sectional design of the 2006 APS and causal relationships could not be determined. In our study, the presence of asthma was determined from a self-report or proxy report of physician-diagnosed asthma. However, the question "Has a doctor told you that you have asthma?" is frequently used to determine the presence of asthma in epidemiological studies of respiratory diseases (26). In addition, self-report of asthma has been shown to have acceptable validity compared with pulmonary test measurements (27). Another limitation was that two administrative modes of data collection - personal and telephone interviews were used in the 2006 APS. These two methods increased the response rate but the data collected by different administrative modes may have varied in terms of quality and validity.

\section{CONCLUSION}

Our study provides valuable information regarding the epidemiology of asthma in Aboriginal children and adults living off reserve in Canada. The increase of asthma prevalence in both children and adults from
2001 to 2006, and the higher asthma prevalence in adults in the Aboriginal population, raises questions that need to be addressed in future research. In addition, variation in prevalence and risk factors of asthma among Aboriginal ancestry groups may be related to genetic and environmental factors that require further investigation.

DISCLAIMER: The research analysis and results are based on data from Statistics Canada and the opinions expressed herein do not represent the views of Statistics Canada.

DISCLOSURES: The authors have no financial disclosures or conflictts of interest to declare.

\section{REFERENCES}

1. Herxheimer H, Schaefer O. Asthma in Canadian Indians (correspondence). N Eng J Med 1974;291:1419.

2. Senthilselvan A, Habbick BF. Increased asthma hospitalizations among registered Indian children and adults in Saskatchewan, 1970-1989. J Clin Epidemiol 1995;48:1277-83.

3. Senthilselvan A, Lawson J, Rennie DR, et al. Stabilization of an increasing trend in physician-diagnosed asthma prevalence in Saskatchewan, 1991-1998. Chest 2003;124:438-8.

4. Sin DD, Wells H, Svenson LW, et al. Asthma and COPD among aboriginals in Alberta, Canada. Chest 2002;121:1841-46.

5. Gao Z, Rowe BH, Majaesic C, O'Hara C, Senthilselvan A. Prevalence of asthma and risk factors for asthma-like symptoms in Aboriginal and non-Aboriginal Children in Northern Territories in Canada. Can Respir J 2008;15:139-45.

6. Stout JW, Sullivan M, Liu LL, et al. Asthma prevalence among American Indian and Alaska Native children. Public Health Reports 1999;114:257-61.

7. Liu LL, Stout JW, Sullivan M, et al. Asthma and bronchiolitis hospitalizations among American Indian children. Arch Pediatr Adolesc Med 2000;54:991-6.

8. Lewis TC, Stout JW, Martinez P, et al. Prevalence of asthma and chronic respiratory symptoms among Alaska Native children. Chest 2004;125:1665-73.

9. Hemmelgarn B, Ernst P. Airway function among Inuit primary school children in far northern Quebec. Am J Respir Crit Care Med 1997;156:1870-6. 
10. Crighton EJ, Wilson K, Senécal S. The relationship between socioeconomic and geographic factors and asthma among Canada's Aboriginal populations. Int J Circumpolar Health 2010;69:138-50.

11. Statistics Canada. 2009. Aboriginal People Survey 2006: Concepts and Methods Guide. Statistics Canada Catalogue no. 89-637-X No 003. Ottawa, Ontario. <www.statcan.gc.ca/pub/89-637-x/89637-x2008003-eng.pdf (Accessed October 19, 2011).

12. Garner R, Kohen D. Changes in the prevalence of asthma among Canadian children. Health Rep 2008;19:45-50.

13. VanGorder TBAKaB. Asthma. Ottawa: Public Health Agency of Canada. 2007 [updated November 22, 2007; cited November 30, 2010]. <www.phac-aspc.gc.ca/publicat/2007/lbrdc-vsmrc/asthmaasthme-eng.php > (Accessed October 19, 2011).

14. Kynyk JA, Mastronarde JG, McCallister JW. Asthma, the sex difference. Curr Opin Pulm Med 2011;17:6-11.

15. Postma DS. Gender differences in asthma development and progression. Gend Med. 2007;(4 Suppl B):S133-46.

16. Midodzi WK, Rowe BH, Majaesic CM, Saunders LD, Senthilselvan A. Early life factors associated with incidence of physician-diagnosed asthma in preschool children: Results from the Canadian Early Childhood Development cohort study. J Asthma 2010;47:7-13.

17. Bjerg A, Rönmark E. Asthma in school age: Prevalence and risk factors by time and by age. Clin Respir J 2008;(2 Suppl 1):123-6.

18. Wade S, Weil C, Holden G, et al. Psychosocial characteristics of inner-city children with asthma: A description of the NCICAS psychosocial protocol. National Cooperative Inner-City Asthma Study. Pediatr Pulmonol 1997;24:263-76.
19. Goodwin RD, Fergusson DM, Horwood LJ. Asthma and depressive and anxiety disorders among young persons in the community. Psychol Med 2004;34:1465-74.

20. Cole TJ, Bellizzi MC, Flegal KM, Dietz WH. Establishing a standard definition for child overweight and obesity worldwide: International survey. BMJ 2000;320:1240-3.

21. Gilliland FD, Berhane K, Islam T, et al. Obesity and the risk of newly diagnosed asthma in school-age children. Am J Epidemiol 2003;1;158:406-15.

22. Ahmad N, Biswas S, Bae S, Meador KE, Huang R, Singh KP. Association between obesity and asthma in US children and adolescents. J Asthma 2009;46:642-6.

23. Suglia SF, Chambera EC, Rosario A, Duarte CS. Asthma and obesity in three-year-old urban children: Role of sex and home environment. J Pediatr 2011;159:14-20.

24. Oddy WH, Sherriff JL, de Klerk NH, et al. The relation of breastfeeding and body mass index to asthma and atopy in children: A prospective cohort study to age 6 years. Am J Public Health 2004;94:1531-7.

25. To T, Wang C, Guan J, McLimont S, Gershon AS. What is the lifetime risk of physician-diagnosed asthma in Ontario, Canada? Am J Respir Crit Care Med 2010;181:337-43.

26. Ferris BG. Epidemiology Standardization Project (American Thoracic Society). Am Rev Respir Dis 1978;118(6 Pt 2):1-120.

27. Senthilselvan A, Dosman JA, Chen Y. Relationship between pulmonary test variables and asthma and wheezing: A validation of self-report of asthma. J Asthma 1993;30:185-93. 


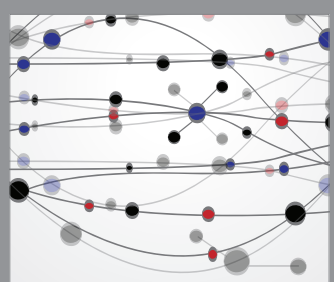

The Scientific World Journal
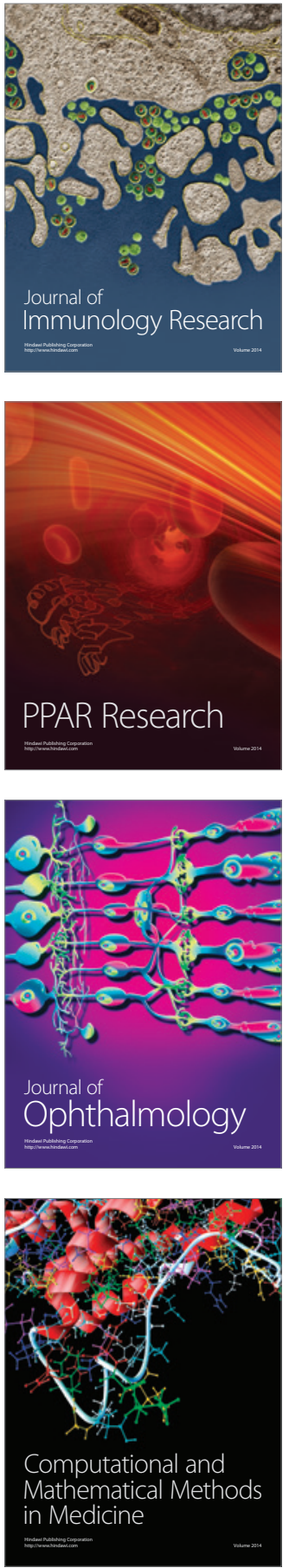

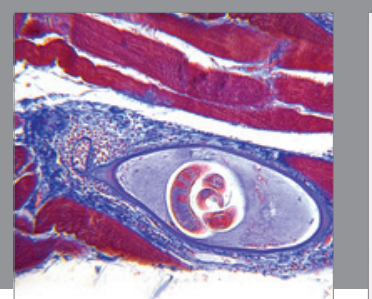

Gastroenterology Research and Practice

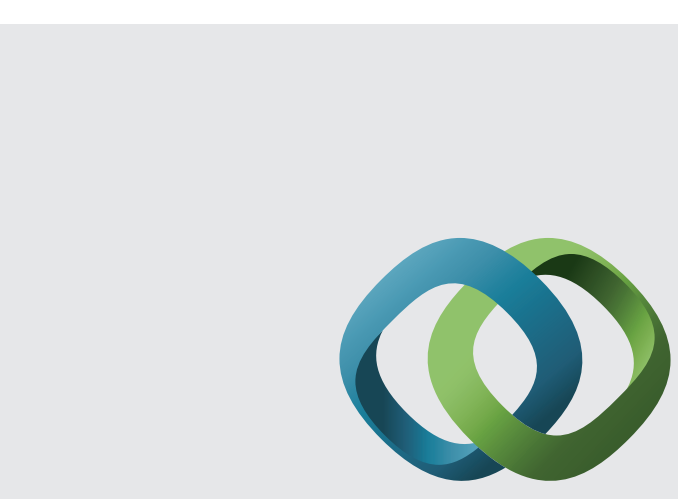

\section{Hindawi}

Submit your manuscripts at

http://www.hindawi.com
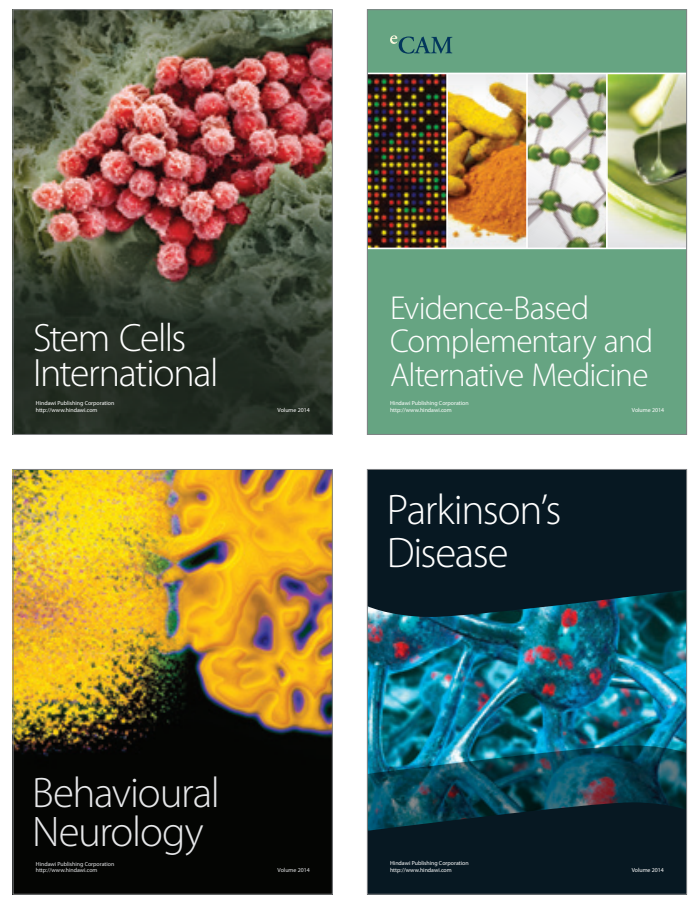
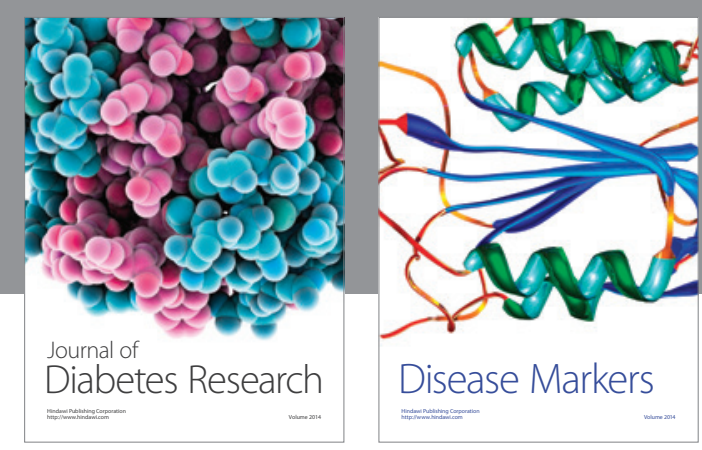

Disease Markers
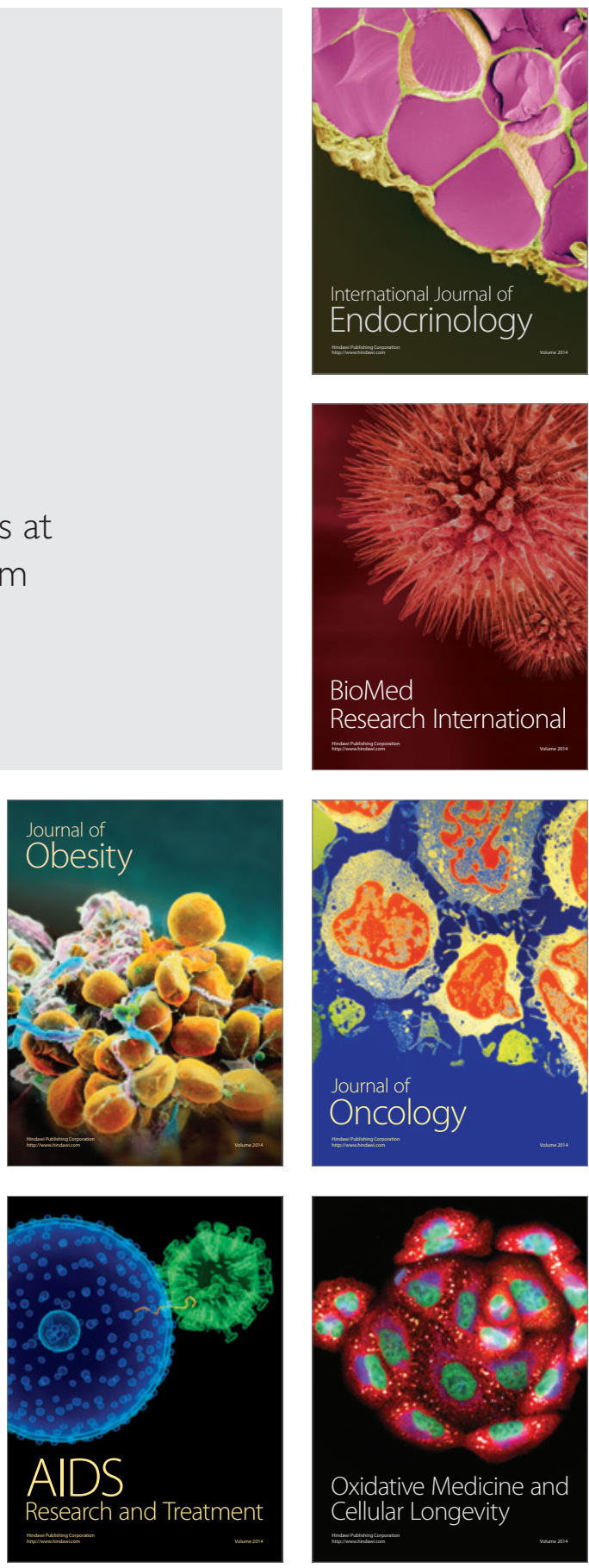